Stanford Studies in Human Rights 


\section{The Rise and Fall of Human Rights}

Cynicism and Politics in Occupied Palestine

Lori Allen 
Stanford University Press

Stanford, California

(C2013 by the Board of Trustees of the Leland Stanford Junior University.

All rights reserved.

No part of this book may be reproduced or transmitted in any form or by any means, electronic or mechanical, including photocopying and recording, or in any information storage or retrieval system without the prior written permission of Stanford University Press.

Printed in the United States of America on acid-free, archival-quality paper Library of Congress Cataloging-in-Publication Data is available from the Library of Congress

ISBN 978-0-8047-8470-2 (cloth : alk. paper)--ISBN 978-0-8047-8471-9 (pbk. : alk. paper) ISBN 978-0-8047-8551-8 (electronic)

Typeset by Bruce Lundquist in 10/14 Minion Pro 
To my parents, Betty and Joe Allen 

This struggle may be a moral one, or it may be a physical one, and it may be both moral and physical, but it must be a struggle. Power concedes nothing without a demand. It never did and it never will. Find out just what any people will quietly submit to and you have found out the exact measure of injustice and wrong which will be imposed upon them, and these will continue till they are resisted with either words or blows, or with both. The limits of tyrants are prescribed by the endurance of those whom they oppress.

Frederick Douglass, 1857

We are not born equal; we become equal as members of a group on the strength of our decision to guarantee ourselves mutually equal rights. Our political life rests on the assumption that we can produce equality through organization, because man can act in and change and build a common world, together with his equals and only with his equals.

Hannah Arendt, 1994 
